\title{
MENINGKATKAN KEMAMPUAN MEMBACA READING COMPREHENSION SISWA KELAS IX-2 DALAM TEXT NARRATIVE DENGAN MENGGUNAKAN TEKNIK JIGSAW
}

\author{
Dra. Nurkhairani \\ MTs Negeri Binjai Kota Binjai
}

\begin{abstract}
ABSTRAK
Penelitian ini bertujuan memperoleh gambaran apakah dengan penerapan metode pembelajaran kooperatif tipe teknik jigsaw dapat mempengaruhi dan meningkatkan minat,motivasi,dan kemampuan membaca dalam Reading Comprehension text narrative siswa kelas IX-2 MTS Negeri Binjai. Subjek penelitian ini adalah kelas IX-2 MTS Negeri Binjai yang berjumlah 40 orang siswa dengan 12 pria dan 28 wanita. Data yang diperoleh adalah dari hasil belajar siswa melalui tes kemampuan setelah proses pembelajaran yang berbentuk tes uraian tertulis secara pribadi dan kegiatan aktivitas siswa dalam belajar melalui pengamatan observer dalam bentuk aspek-aspek penilaian yang berkaitan dengan tujuan pembelajaran membaca reading comprehension text narrative. Adapun pelaksanaan penelitian dilakukan dalam tiga siklus. Setiap siklus melalui tahapan perencanaan,pelaksanaan tindakan,observasi dan refleksi yang hasilnya dipaparkan dalam bentuk tabel dan uraian. Dari hasil analisis data pada siklus 1 aktivitas dan hasil belajar belum memuaskan,masih termasuk dalam kategori kurang mampu dengan tingkat pencapaian $56,21 \%$ dan hasil belajar dengn nilai 64,35 di kategorikan tidak tuntas.Pada siklus II sudah dimulai ada perubahan aktivitas belajar dengan kategori cukup tingkat pencapaian $63,73 \%$ dan hasil belajar dengan nilai rata-rata 63,07 dikategorikan tidak tuntas. Pada siklus III aktivitas belajar rata-rata sudah dikatakan mampu dengan kategori baik tingkat pencapaian $75,16 \%$ dan hasil belajar dapat dikatakan tuntas dengan rata-rata nilai 72,82. Dengan demikian dapat disimpulkan bahwa aktivitas belajar dan hasil belajar siswa dengan strategi atau teknik pembelajaran model jigsawdapat meningkatkan minat,motivasi,dan kemampuan belajar siswa membaca pemahaman pada text narrative.
\end{abstract}

Kata kunci : teknik jigsaw, reading comprehension text narrative

\section{PENDAHULUAN}

Dalam ketrampilan membaca siswa diharapkan mampu memahami makna teks tulis fungsional pendek dan esai sederhana berbentuk deskriptif(descriptive,procedure,dan report)dan narrative(narrative dan recount)dalam konteks kehidupan sehari-hari dengan cara mengidentifikasi gagasan utama,informasi inci tersurat,informasi tersirat,rujukan kata,makna kata,frasa dan kalimat(termasuk kosakata,tata bahasa dan ciriciri kebahasaan lainnya yang terkait dengan jenis teks dan tema (Kurikulum Bahasa Inggris SMP dan MTS, 2006). Kegiatan membaca merupakan aktifitas berbahasa yang memerlukan kemampuanspesifik yaitu mampu memadukan factor internal (dalam)dan factor exsternal (luar)pembaca yaitu factor factor yang ada saling berhubungan membentuk semacam koordinasi yang rumit untuk pemahaman terhadap becaan.Ada saatnya pada saat tahap membaca tertentu,kemampuan intelektual dibutuhkan factor pengetahuan,pengalaman dan persepsi untuk menelaah,menyintetis,menilai atau membuat imajinasi.

Sebaiknya pembaca tahu suatu tujuan membaca karena seseorang yang. Melakukan membaca dengan suatu tujuan, cenderung lebih memahami. Dibandingkan dengan orang yang 
tidak mempuyai tujuan . Tujuan Keterampilan. Membaca tingkat SMP/MTS adalah siswa diharapkan mampu memahamin makna. Teks tulis fungsional pendek dan esei sederhana berbentuk deskriptif dan narrative. Dalam konteks kehidupan sehari-hari dengan cara mengidentifikasi; gagasan. Utama, informasi rinci tersurat, informasi tersirat, rujukan kata, makna kata, frasa Dan kalimat (Kurikulum Bahasa Inggris 2006).

Dalam hal ini keterampilan membaca sangat menentukan keberhasilan dalam membaca,tidak hanya mampu mengenali lambing bunyi berupa symbol-simbolyang dituliskan,tetapi meliputi keterampilan memahami dan mencerna makna yang tersirat dan tersurat dari bacaan itu,kecepatan membaca dan pemahaman isi bacaan secara keseluruhan (D.P.Tampubolon, 2003:7). Pengharapan dan pencapaian akan kemampuan dan ketrampilan membaca bahasa Inggris secara metode pembelajaran yang disebutkan diatas berdasarkan pengalaman tertulis dalam penyelenggaraan pembelajaran di kelas IX MTS Negeri Binjai sangat jauh sebagaimana yang diharapkan.ini terlihat dari rendahnya minat dan motivasi siswa dalam belajar sehingga masih banyak twrdapat siswa siswa yang kurang mampu dan bahkan ada yang tidak memahami isi teks suatu bacaan walaupun ada yang mampu dierkirakan hanya $30 \%$ saja. Rendahnya minat dan motivasi membaca serta penguasaan perbendaharaan kosa kata yang dimiliki siswa dan kurang menariknya metode dan strategi mengajar membacayang diterapkan dan kurangnya daya saing antarsiswa adalah merupakan penyebab rendahnya kemampuan membaca khususnya membaca pemahaman.Pembelajaran selalu dibantu oleh guru dengan membacakan teks serta menterjemahkan kemudian mminta siswa menjawab pertanyaan berdasarkan bacaan.
Untuk mengatasi fenomena masalah yang dihadapi sebagai penyelenggara pembelajaran diperlukan upaya menginovasi pembelajaran dengan mendesain suatu metode pembelajaran diskusi yaitu pembelajaran kooperatif. Dewasa ini model pembelajaran kooperatif telah banyak dilakukan pada semua tingkat kelas dan dapat digunakan pada banyak bidang studi sepertu sains,matematika,agama dan bahasa Inggris dan bidang studi lainnya. Metode pembelajaran kooperatif akan melatih siswa untuk mendengarkan pendapat orang lain.Tugas-tugas kelompok akan dapat memacu siswa untuk saling bekerja dan mengembangkan segala potensi yang dimilikinya,saling mmbantu satu sama lain dalam mengintegrasikan pengetahuanpengetahuan baru dengan yang dimilikinya. Ada beberapa tipe pembelajaran kooperatif,salah satunya model pembelajaran kooperatif jigsaw. Lie(2004) menyatakan bahwa ,jigsaw merupakan salah satu metode pembelajaran kkoperatif yang bersifat fleksibel,beberapa penelitian secara konsisten menunjukkan bahwa model pembelajaran kooperatif jigsaw memiliki dampak yang positif terhadap kegiatan pembelajaran.

Pada model pembelajaran jigsaw, siswa melakukan pertukaran anggota kelompok dari satu kelompok ke kelompok lain,dimana setiap siswa memiliki informasi yang berbeda.Setiap siswa mengajarkan dn memberi informasi kepada anggota kelompok yang lain sesuai dengan topic pembahasan yang dimiliki siswa. Model pembelajaran ini diharapkan dapat meningkatkan tanggung jawab dalam berdiskusi dan siswa dengan guru.

Model pembelajaran kooperatif tipe jigsaw merupakan salah satu strategi yang dapat digunakan oleh guru kepada siswa 
sebagai usaha menciptakan komperasi siswa dalam bentuk keaktifan siswa melalui respon terhadap apa yang telah diberikan guru dan terjadi pada proses belajar mengajar. Tipe ini pada mulanya dikembangkan oleh Elliot Aronson dan kawan- kawannya dari Universitas Texas dan kemudian diadaptasikan oleh Slavin dan kawan-kawanya di Universitas Jhon Hopkins.Bagian yang terpenting dalam Model pembelajaran jigsaw ini adalah adanya kerjasama anggota kelompok dan komperansi antara kelompok untuk belajar dari temannya serta mengajar temannya. Guru memperhatikan schemata atau latar belakang pengalaman siswa dan Membantu siswa mengaktifkan schemata ini agar bahan pelajaran menjadi lebih bermakna. Selain itu siswa bekerja demgan sesame siswa dalam suasana gotong royong dan mempuyai banyak kesempatan mengolah informasi dan meningkatkan berkomunikasi (Lie ;2004).

Pembelajaran kooperatif jigsaw dapat mengingkatkan rasa tanggung jawab siswa terhadap pembelajarannya sendiri dan juga pembelajaran orang lain.Siswa tidak hanya mempelajarin materi yang diberikan, tetapi meraka juga harus siap memberikan dan mengajarkan materi tersebut pada anggota kelompoknya yang lain. Dengan demikian, siswa saling tergantung satu dengan yang lain dan harus bekerja sama secara kooperatif untuk mempelajarin materi yang ditugaskan.Para anggota dari tim yang berbeda dengan topic yang sama bertemu untuk diskusi(tim ahli) saling membatu satu sama lain tentang topik pembelajaran yang ditugaskan kepada mereka. Kemudian siswa-siswa itu kembali pada tim atau kelompok asal untuk menjelaskan kepada anggota kelompok yang lain tentang apa yang telah mereka pelajarin sebelumnya pada pertemuan tim ahli.
Kunandar (2008 :365) menguraikan langkah-langkah tipe jigsaw sebagai berikut :

\section{Kelompok cooperative (awal)}

a.Siswa dibagi ke dalam kelompok kecil 3-6 siswa

b.wacana atau tugas akademik dibagikan yang sesuai dengan materi yang diajarkan

c.Masing-masing siswa dalam kelompok mendapatkan wacana atau tugas yang berdabeda dan memahamin informasi yang ada didalamnya.

\section{Kelompok Ahli}

a.Masing-masing siswa yang memiliki wacana atau tugas yang sama dalam satu kelompok dikumpulkan sehingga jumlah sehingga jumlah kelompok ahil sesuai dengan wacana atau tugas yang telah dipersiapkan oleh guru.

b.Dalam kelompok ahli ini ditugaskan agar siswa belajar bersama untuk menjadi ahli sesuai dengan wacana atau tugas yang menjadi tanngung jawabnya.

c.Semua anggota kelompok ahli ditugaskan untuik memahami dan dapat menyampaikan informasi tentang hasil dari wacana atau tugas yang telah dipahami kepada kelompok awal

d.Masing-masingsiswa kembali ke krlompok awal setelah menyelesaikan tugas yang dikerjakan dalam kelompok ahli

e.Masing-masing siswa secara bergiliran menyampaikan hasil dari tugas di kelompok ahli

f.Setelah kelompok menyelesaikan tuganya, secara keseluruhan masing-masing kelompok melaporkan hasilnya dan guru memberikan klarifikasi.

Text narrative merupakan salah satu jenis text yang lahir dari suatu konteks budaya sebagai alat komunikasi yang dapat digunakan dalam kehidupan sehari-hari untuk 
menceritakan atau gambaran kejadian-kejadian dalam suatu cerita. Text narrative ini bersifat imjiner tetapi terkadang ada juga factual atau kejadian-kejadian sesungguhnya. Jenis-jenis isi ceritanya dapat merupakan dalam bentuk dongeng (fairy stories), cerita misteri,science fiction, roman, horror, dan lain-lain.

\section{METODE PENELITIAN}

Penelitian ini mengambil lokasi di Madrasah Tsanawiyah Negri (MTsN) Binjai yang beralamat dijalan pekan baru di NO.2A Binjai di ambil penulis mengambil lokasi atau tempat ini dengan pertimbangan adallah mengajar di madrasah tersebut sehingga memudahkan dalam,pencarian data peluang waktu yang cukup banyak dan subjek penekiti yang sesuai dengan peneliti ini dilaksanakan selama 3 bulan mulai dari bulan september sampai dengan bulan November. Subjek penelitian ini adalah siswa 1X -2 MTs Negeri Binjai dengan jumlah siswa 40 orang dengan siswa laki laki 12 orang dan siswa perempuan 28 0rang.

\section{Prosedur penelitian}

Prosedur penelitian ini dilakukan melalui tahapan sebagai berikut:

\section{Perencanaan}

a.menentukan bahan bacaan atau materi pembelajaran

b.Menyiapkan pembelajaran berupa rencana pelaksaan pembelajaran RPP

c.Menyediakan lembaran kerja siswa

d.Mepersiapkan dan membuat media atau alat bantu pengajaran yang dilakukan

e.Membuat evaluasi
f.Menyiapkan dan membut lembaran observasi yang digunakan aktivitas belajar siswa

\section{Pelaksaan tindakan}

a. Melaksaakan kegiatan pembelajaran dikelas berdasarkan RPP yang telah di persiapkan

b. Memberikan materi pembelajaran mulai menerapkan strategi kooperaktif jigjaw

c. Mengelompkkkan siswa dalam beberapa kelompok belajar yang merupakan kelompok yang sama yang terdiri dari 5-6 siswa setiap siswa di beri nomor berdasarkan faragraf

d. Membagikan potongan potongan paragrafh yang berbeda dalam bentuk text yang berkaitan dengan judul materi pelajaran.

e. Membentuk kelompok ahli yang terdiri dari siswa siswa yang memiliki potongan paragraf potongan sama atau degan nomer yang sama

f. Membahas materi pembelajaran melalui materi pembelajaran melalui kegiatan:

\section{Memahami arti dalam paragraf}

2. Membagi ninformasi yang ada yang ada dalam paragraf sebagai tanggung jawab masing masing dalam kelompok asli

3. Memberikan penjelasan tentang informasi yang di dapat dalam kelompok ahli kepada kelompok asal

4.Menjawab pertnyaan yang bersifat umum PTK

a.Melakukan pengolahan hasil observasi aktuvitas dan hasil kemampuan belajar siswa dilakukan dengan rumus tingkat pencapaian hasil belajar sebagai berikut :

Perolehan nilai $=\frac{\text { Skor } \text { yang diperoleh sisa }}{\text { skor } \text { maksimum }} \times 1000$ 
Kriteria ketuntasan belajar yang digunakan sebagai berikut:

$0<$ perolehan Nilai $<65$ artinya siswa belum tuntas belar

$65<$ Perolehan nilai $<100$ qrtinyq siswa telas lulus belajar

$\%$ Ketuntasan kelas $=\frac{\text { Jumlah siswa yang lulus }}{\text { Jumlah siswa keseluruhan }} \times 100 \%$

Kriteria kategori penilaian pencapaian menggunakan rentang sebaagai berikut:

Kategori penilaian :

$\begin{array}{lll}80-100 & \text { : Baik sekali } & \text { (A) } \\ 70-90 & \text { : Baik } & \text { (B) } \\ 60-69 & \text { : Cukup } & \text { (c) } \\ 50-59 & \text { : Kurang } & \text { (D) } \\ 0-49 & \text { : Sangat kurang } & \text { (E) }\end{array}$

2.Mengembangkan hasil analisa tes untuk melihat kemajuan belajara siswa sebagain acuan untuk siklus berikutnya.

\section{Analisa data}

Penelitian ini menggunakan teknik analisa kualitatif yang interaktif kunandar (2008:101) analisis interaktif terdiri 3 komponen aktif yang saling terkait satu sama lain yaitu: reduksi data reduksi terdiri dari beberapa (display) data dan penarikan kesimpulan.

1. Reduksi data : proses menyeleksi menentukan

fokus,menyederhanakan,meringkas

dan mengubah bentuk data mentah yang ada data dalam catatan lapangan.

2. Beberan (diaplay) : berbagai macam data PTK yang telah di reduksi di beberkan yang telas betata rapi dengan tabel.
3. Penarikan kesimpulan : penarikan kesimpulan tentsng peningkatan atau perubahan yang terjadi yang di lakukan secara bertahap mulai dari kesimpulan sementang di tarik pada akhir siklus satu kesimpulan tervisi pada akhir siklus dan kesimpulan terakhir pada siklus terakhir.

\section{HASIL DAN PEMBAHASAN PENELITIAN \\ Proses Analisis Data}

\section{Siklus I}

Dalam proses pembelajaran siklus pertama menyajikan dengan memperkenalkan materi teks narrative dan cara cara kelompok belajar tipe Jigsaw dengan teks narrative Malin Kundang dari aktivitas belajar siswa yang terdiri dari aspek-aspek tujuan pembelajaran diperoleh hasil sebagai berikut :

Tabel 1. Aktivitas dan Hasil Belajar Siswa

\begin{tabular}{|c|c|c|c|c|c|}
\hline No & Nama Siswa & $\begin{array}{l}\text { Akt. } \\
\text { Belajar }\end{array}$ & Kategori & $\begin{array}{l}\text { Hasil } \\
\text { Belajar }\end{array}$ & Kategori \\
\hline 1. & Abdul Razaq & 33.33 & Sangat Kurang & 60 & Tdk Tuntas \\
\hline 2. & Aditya & 41.66 & Sangat Kurang & 60 & Tdk Tuntas \\
\hline 3. & Agung Prasetyo & 83.33 & Baik Sekali & 65 & Tuntas \\
\hline 4. & Anisyah Destika & 50 & Kurang & 65 & Tuntas \\
\hline 5. & Anugrah Pratama & 66.66 & Cukup & 70 & Tuntas \\
\hline 6. & Apriandi Nanda P & 33.33 & Sangat Kurang & 60 & Tdk Tuntas \\
\hline 7. & Arisa Rifani & 33.33 & Sangat Kurang & 50 & Tdk Tuntas \\
\hline 8. & Dea Jesika & 91.66 & Baik Sekali & 70 & Tuntas \\
\hline 9. & Evalin Saidah & 75 & Baik & 60 & Tdk Tuntas \\
\hline 10. & Hariansyah P & 50 & Kurang & 65 & Tuntas \\
\hline 11. & Juliani & 41.33 & Sangat Kurang & 60 & Tdk Tuntas \\
\hline 12. & Khairani Nst & 66.66 & Cukup & 65 & Tuntas \\
\hline 13. & Khairunnisa & 33.33 & Sangat Kurang & 60 & Tdk Tuntas \\
\hline 14. & Lailan Azizah & 33.33 & Sangat Kurang & 40 & Tdk Tuntas \\
\hline 15. & Lia Novita Mandasari & 50 & Kurang & 60 & Tdk Tuntas \\
\hline 16. & Lismayanti & 66.66 & Cukup & 60 & Tdk Tuntas \\
\hline 17. & Linia Indira & 33.33 & Sangat Kurang & 60 & Tdk Tuntas \\
\hline 18. & M.Ali Tambusai & 33.33 & Sangat Kurang & 65 & Tuntas \\
\hline 19. & M.IbalSaipul & 100 & Baik Sekali & 70 & Tuntas \\
\hline 20. & Maymunnah & 58.33 & Kurang & 60 & Tdk Tuntas \\
\hline 21. & Nurmaidah & 50 & Kurang & 45 & Tdk Tuntas \\
\hline 22. & Nur Amalia & 58.33 & Kurang & 60 & Tdk Tuntas \\
\hline 23. & Nur Azizah & 50 & Kurang & 60 & Tdk Tuntas \\
\hline 24. & Nur Amalia & 66.66 & Cukup & 65 & Tuntas \\
\hline 25. & Nurul Hidayah & 66.66 & Cukup & 70 & Tuntas \\
\hline 26. & Pranmita & 50 & Kurang & 65 & Tuntas \\
\hline 27. & Rangga Pramudya & 100 & Baik Sekali & 70 & Tuntas \\
\hline 28. & Randi Almulz & 41.33 & Sangat Kurang & 65 & Tuntas \\
\hline 29. & Riza Zuana & 50 & Kurang & 50 & Tdk Tuntas \\
\hline 30. & Rizky Mardatilla & 50 & Kurang & 50 & Tdk Tuntas \\
\hline 31. & Shella Burviana & 91.66 & Baik Sekali & 60 & Tdk Tuntas \\
\hline 32. & Siti Fahrum & 83.33 & Baik & 65 & Tuntas \\
\hline 33. & Sulastri & 58.33 & Kurang & 55 & Tdk Tuntas \\
\hline 34. & Sri Hartati & 75 & Baik & 70 & Tuntas \\
\hline 35. & Sri Ramadhani & 33.33 & Sanagt Kurang & 50 & Tdk Tuntas \\
\hline 36. & Wahyu Andri & 75 & Baik & 70 & Tuntas \\
\hline 37. & Wirda Purwanti & 58.33 & Kurang & - & \\
\hline 38. & Yulia Mandasari & 41.33 & Sangat Kurang & 60 & Tdk Tuntas \\
\hline 39. & Yuni Ida Kusuma & 33.33 & Sangat Kurang & 60 & Tdk Tuntas \\
\hline \multirow[t]{2}{*}{40.} & Yunisa Iilhamiyah & 41.33 & Sangat Kurang & 55 & Tdk Tuntas \\
\hline & Jumlah rata-rata & 56,21 & Kurang & 64,35 & Tdk Tuntas \\
\hline
\end{tabular}

Tabel 2. Persentase Aktifitas Belajar Siswa 


\begin{tabular}{llrll} 
& & & & \\
\cline { 3 - 5 } & & Kategori & $\mathrm{F}$ & $\%$ \\
\hline 1. & Memahami arti & -Mampu & 12 & $30 \%$ \\
& kata dalam & -Kurang mampu & 11 & $27 \%$ \\
& paragraf & -Tdk Mampu & 17 & $42.5 \%$ \\
\hline 2. & Memahami & -Mampu & 6 & 15 \\
& informasi pada & -Kurang Mampu & 15 & $37.5 \%$ \\
& kelompok ahli & -Tdk Mampu & 19 & $47.5 \%$ \\
\hline 3. & Memberikan & -Mampu & 8 & $20 \%$ \\
& penjelasan pada & -Kurang Mampu & 10 & $25 \%$ \\
& kelompok asal & -Tdk Mampu & 22 & $55 \%$ \\
\hline 4. & Menjawab & -Mampu & 7 & $17.5 \%$ \\
& pertanyaan & -Kurang Mampu & 10 & $24 \%$ \\
& bersifat umum & -Tdk Mampu & 23 & $57 \%$
\end{tabular}

Persentase Belajar diperoleh dengan perhitungan :

$\%$ ketuntasan kelas $=\frac{\text { Jumlah siswa yang lulus }}{\text { Jumlah siswa keseluruhan }} \times 100 \%$

$\%$ ketuntasan kelas $=\frac{16}{40} \times 100 \%=40 \%$

\section{Interpretasi}

Dari tabel diatas dapat dikatakan aktivitas belajar masih kurang dengan rata-rata $56,21 \%$ dan hasil belajar siswa yang tuntas hanya $33.33 \%$ dan tidak tuntas $66.66 \%$. Pengenalan materi perlu di perjelas dalam kelompok dan sebaiknya disampaikan oleh anggota kelompok. Antar kelompok belum memahami metode pembelajaran dan bentuk tes uraian perlu di analisa kembali sehingga proses pembelajaran masih kurang.

\section{Siklus II}

Tabel 3. Aktivitas dan Hasil belajar siswa

\begin{tabular}{|c|c|c|c|c|c|}
\hline No. & Nama Siswa & $\begin{array}{c}\text { Aktivitas } \\
\text { belajar }\end{array}$ & Kategori & $\begin{array}{c}\text { Hasil } \\
\text { Belajar }\end{array}$ & Kategori \\
\hline 1. & Abdur Razaq & 33.33 & Sgt kurang & 65 & Tuntas \\
\hline 2. & Aditya & 41.66 & Sgt Kurang & 75 & Tuntas \\
\hline 3. & Agung Prasetyo & 83.33 & Baik & 60 & Tdk Tuntas \\
\hline 4. & Anisyah Destika & 75 & Baik & 60 & Tdk Tuntas \\
\hline 5. & Anugrah Pratama & 66.66 & Cukup & 70 & Tuntas \\
\hline 6. & Apriandi nanda $\mathrm{P}$ & 50 & Kurang & 60 & Tdk Tuntas \\
\hline 7. & Arisa Rifani & 50 & Kurang & 60 & Tdk Tuntas \\
\hline 8. & Dea Jeskha & 100 & Baik Sekali & 75 & Tuntas \\
\hline 9. & Evali Saidah & 75 & Baik & 60 & Tdk Tuntas \\
\hline 10. & Hariansyah P & 75 & Baik & 60 & Tdk Tuntas \\
\hline 11. & Jualiani & 75 & Baik & 60 & Tdk Tuntas \\
\hline 12. & Khairani Nts & 75 & Baik & - & \\
\hline 13. & Khairunnisa & 75 & Baik & 60 & Tdk Tuntas \\
\hline 14. & Lailan Azizah & 33.33 & Sgt Kurang & 40 & Tdk Tuntas \\
\hline 15. & Lia Novita M & 66.66 & Cukup & 60 & Tdk Tuntas \\
\hline 16. & Lismayanti & 83.33 & Baik & 70 & Tuntas \\
\hline 17. & Linia Indira & 66.66 & Cukup & 65 & Tuntas \\
\hline 18. & M.Ali Tambusai & 41.33 & Sgt Kurang & 55 & Tdk Tuntas \\
\hline 19. & m.Iqbal Saipul & 100 & Baik Sekali & 65 & Tuntas \\
\hline 20. & Maymunnah & 50 & kurang & 65 & Tuntas \\
\hline 21. & Nurmaidah & 75 & Baik & 70 & Tuntas \\
\hline 22. & Nursadah & 58.33 & Kurang & 75 & Tuntas \\
\hline 23. & Nur Azizah & 50 & Kurang & 60 & Tdk Tuntas \\
\hline
\end{tabular}

\begin{tabular}{clllll}
\hline 24. & Nurul Amalia & 58.33 & Kurang & 60 & Tdk Tuntas \\
\hline 25. & Nurul Hidayah & 83.33 & Baik & 65 & Tuntas \\
\hline 26. & Pranmita & 66.66 & Cukup & 60 & Tdk Tuntas \\
\hline 27. & Rangga Pramudya & 100 & Baik Sekali & 70 & Tuntas \\
\hline 28. & Randi Almulz & 58.33 & Kurang & 70 & Tuntas \\
\hline 29. & Riza Zuana & 50 & Kurang & 50 & Tdk Tuntas \\
\hline 30. & Rizky Mardatilla & 58.33 & Kurang & 65 & Tuntas \\
\hline 31. & Shella Burviana & 83.33 & Baik & 80 & Tuntas \\
\hline 32. & Siti Fahrum & 50 & Kurang & 60 & Tdk Tuntas \\
\hline 33. & Sulastri & 58.33 & Kurang & 65 & Tuntas \\
\hline 34. & Sri Hartati & 66.66 & Cukup & 60 & Tdk Tuntas \\
\hline 35. & Sri Ramadhani & 33.33 & Sgt Kurang & 50 & Tdk Tuntas \\
\hline 36. & Wahyu Andri & 83.33 & Baik & 70 & Tuntas \\
\hline 37. & Wirda Purwanti & 83.33 & Baik & 65 & Tuntas \\
\hline 38. & Yulia Mandasari & 50 & Kurang & 60 & Tdk Tuntas \\
\hline 39. & Yuni Ida Kusuma & 41.66 & Sgt Kurang & 60 & Tdk Tuntas \\
\hline 40. & Yunisa Iihamiyah & 50 & Kurang & 60 & Tdk Tuntas \\
\hline & Jumlah & 63.73 & Cukup & 63.07 & Tdk Tuntas \\
\hline
\end{tabular}

Tabel 4. Persentase Aktifitas Belajar Siswa

\begin{tabular}{lllll}
\hline \multirow{2}{*}{ No } & Aspek penilaian & \multicolumn{3}{c}{ Persentase } \\
\cline { 3 - 5 } & & Kategori & F & $\%$ \\
\hline 1. & Memahami arti kata & -Mampu & 14 & $35 \%$ \\
& dalam paragraf & -Kurang Mampu & 15 & $37 \%$ \\
& & -Tdk Mampu & 11 & $27.5 \%$ \\
\hline 2. & Memahami & -Mampu & 11 & $32.5 \%$ \\
& informasi pada & -Kurang Mampu & 16 & $40 \%$ \\
& kelompok ahli & -Tdk Mampu & 11 & $27.5 \%$ \\
\hline 3. & Memberikan & -Mampu & 13 & $32.5 \%$ \\
& penjelasan pada & -Kurang Mampu & 14 & $35 \%$ \\
& kelompok asal & Tdk Mampu & 13 & $32.5 \%$ \\
\hline 4. & Menjawab & -Mampu & 12 & $30 \%$ \\
& pertanyaan bersifat & -Kurang Mampu & 15 & $37.5 \%$ \\
& umum & -Tdk Mampu & 13 & $32.5 \%$ \\
\hline
\end{tabular}

Persentasi Belajar diperoleh dengan perhitungan sebagai beriku :

$\%$ ketuntasan kelas $=\frac{\text { Jumlah } \text { siswa yang tulus }}{\text { Jumlah siswa keseluruhan }} \mathrm{X} 100 \%$

$\%$ ketuntasan kelas $=\frac{18}{38} \times 100 \%=46.15 \%$

Tabel 5. Aktivitas dan Hasil Belajar Siswa

\begin{tabular}{|c|c|c|c|c|c|}
\hline NO & Nama Siswa & $\begin{array}{l}\text { Aktivitas } \\
\text { Belajar }\end{array}$ & Kategori & $\begin{array}{l}\text { Hasil } \\
\text { Belajar }\end{array}$ & Kategori \\
\hline 1. & Abdur Razaq & 33.33 & Sgt Kurang & 60 & Tdk Tuntas \\
\hline 2. & Aditya & 75 & Baik & 75 & Tuntas \\
\hline 3. & Agung prasetyo & 75 & Baik & 70 & Tuntas \\
\hline 4. & Anisyah Desika & 100 & Baik Sekali & 75 & Tuntas \\
\hline 5. & Anugrah Pratama & 83.33 & Baik & 80 & Tuntas \\
\hline 6. & Apriandi Nanda P & 41.33 & Sgt Kurang & 75 & Tuntas \\
\hline 7. & Arisa Rifani & 41.33 & Sgt Kurang & 50 & Tdk Tuntas \\
\hline 8. & Dea Jesikha & 100 & Baik Sekali & 70 & Tuntas \\
\hline 9. & Evalin Saidah & 100 & Baik Sekali & 70 & Tuntas \\
\hline 10. & Hariansyah P & 83.33 & Baik & 75 & Tuntas \\
\hline 11. & Jualiani & 50 & Kurang & 75 & Tuntas \\
\hline 12. & Khairani Nst & - & & - & - \\
\hline 13. & Kharunissa & 100 & Baik Sekali & 65 & Tdk Tuntas \\
\hline 14. & Lailan Azizah & 41.33 & Sgt Kurang & 60 & Tdk Tuntas \\
\hline 15. & Lia Novita M & 75 & Baik & 75 & Tuntas \\
\hline 16. & Lismayanti & 83.33 & Baik & 80 & Tuntas \\
\hline 17. & Linia Indria & 83.33 & Baik & 70 & Tuntas \\
\hline 18. & M.Ali Tambusai & 41.33 & Sgt Kurang & 60 & Tdk Tuntas \\
\hline 19. & M.Iqbal Saipul & 100 & Baik Sekali & 85 & Tuntas \\
\hline 20. & Maymunnah & 58.33 & Cukup & 75 & Tuntas \\
\hline 21. & Nurmaidah & 100 & Baik Sekali & 65 & Tdk Tuntas \\
\hline 22. & Nursaadah & 91.66 & Baik Sekali & 70 & Tdk Tuntas \\
\hline 23. & Nur Azizah & 100 & Baik Sekali & 85 & Tdk Tuntas \\
\hline 24. & Nurul Amalia & 91.66 & Baik Sekali & 80 & Tuntas \\
\hline 25. & $\begin{array}{l}\text { Nurul Hidayah } \\
\end{array}$ & 100 & Baik Sekali & 70 & Tuntas \\
\hline 26. & $\begin{array}{l}\text { Pranmita } \\
\end{array}$ & 66.66 & Cukup & 80 & Tuntas \\
\hline
\end{tabular}




\begin{tabular}{clcccc}
\hline 27. & Rangga Pramudya & 100 & Baik Sekali & 70 & Tuntas \\
\hline $\mathbf{2 8}$. & Randi Almuz & 66.66 & Cukup & 70 & Tuntas \\
\hline $\mathbf{2 9}$. & Riza Zuana & 41.3 & Sgt Kurang & 60 & Tdk Tuntas \\
\hline $\mathbf{3 0}$. & Rizky Mardatilla & 83.33 & Baik & 50 & Tdk Tuntas \\
\hline $\mathbf{3 1}$. & Shella Burviana & 100 & Baik Sekali & 75 & Tuntas \\
\hline $\mathbf{3 2}$. & Siti Fahrum & - & & - & - \\
\hline $\mathbf{3 3 .}$ & Sulastri & 89.33 & Baik & 60 & Tdk Tuntas \\
\hline $\mathbf{3 4}$. & Sri Hartati & 41.33 & Sgt Kurang & 75 & Tuntas \\
\hline $\mathbf{3 5}$. & Sri Ramadhani & 66.66 & Cukup & 55 & Tdk Tuntas \\
\hline $\mathbf{3 6}$. & Wahyu Andri & 91.66 & Baik Sekali & 70 & Tuntas \\
\hline $\mathbf{3 7 .}$ & Wirda Purwani & 91.66 & Baik Sekali & 80 & Tuntas \\
\hline $\mathbf{3 8 .}$ & Yulia Mandasari & 66.66 & Cukup & 75 & Tuntas \\
\hline $\mathbf{3 9}$. & Yuni Ida Kusuma & 50 & Sgt Kurang & 75 & Tuntas \\
\hline $\mathbf{4 0}$ & Yunisa Ilhamiyah & 58.33 & Kurang & 80 & Tuntas \\
\hline & Jumlah Rata-rata & 75,16 & & 72,82 & Tuntas \\
\hline
\end{tabular}

Tabel 6. Persentase Aktifitas Belajar Siswa

\begin{tabular}{cllcc}
\hline \multirow{2}{*}{ NO } & & \multicolumn{2}{c}{ Persentase } \\
\cline { 3 - 5 } & Aspek & \multicolumn{1}{c}{ Kategori } & F & $\%$ \\
& Penilaian & & & \\
\hline $\mathbf{1 .}$ & Memahami arti & - Mampu & 20 & $52,63 \%$ \\
& kata dalam & - Kurang Mampu & 9 & $23,68 \%$ \\
& paragraf & - Tdk Mampu & 9 & $23,68 \%$ \\
& & & \\
\hline $\mathbf{2}$ & Memahami & -Mampu & 20 & $52,63 \%$ \\
& informasi pada & -Kurang mampu & 8 & $21,05 \%$ \\
& kelompok ahli & - Tdk mampu & 10 & $26,31 \%$ \\
& & & \\
& & & 19 & $47,5 \%$ \\
$\mathbf{3}$ & Memberikan & -Mampu & 12 & $31,51 \%$ \\
& penjelasan & - Kurang mampu & 7 & $18,42 \%$ \\
& pada kelompok & - Tdk mampu & & \\
\hline asal & & 18 & $47,36 \%$ \\
$\mathbf{4}$ & Menjawab & -Mampu & 9 & $23,68 \%$ \\
& Pertanyaan & -Kurang mampu & 11 & $28,94 \%$
\end{tabular}

Persentase hasil belajar diperoleh dengan perhitungan siswa seebagai berikut:

$\%$ ketuntasan kelas $=$ Jumlah siswa yang lulus $\quad X 100 \%$ Jumlah siswa keseluruhan

$\%$ Ketuntasan kelas $=\underline{30} \times 100 \%=76.92 \%$ 39

\section{KESIMPULAN}

Berdasarkan analisis data data yang diperoleh dari hasil aktivitas dan hasil pembelajaran siswa dengan penerapan strategi kooperatif tipe jigsaw dapat disimpulkan sebagai berikut :

1. Penerapan strategi atau teknik pembelajaran kooperatif tipe jigsaw dikelas IX-2 MTs Negri Binjai ternyata dapat meningkatkan aktivitas belajar siswa. Hal ini dapat dilihat pada siklus pertama adalah 56,21 adalah dengan kategori kurang dan siklus kedua 63,73 dengan kategori cukup sedangkan siklus ketiga mengalami peningkatan dengan nilai 75,16 .

2. Dengan meningkatnya aktivitas belajar siswa ternyata mempengaruhi hasil belajar siswa. Hal ini dapat dilihat dari nilai rata rata siklus pertama 64,35 dan siklus kedua dengan nilai 63,07 dan pada siklus ketiga mengalami peningkatan dengan nilai 72,82. Walaupun ddemikian masih ada beberapa siswa yang memiliki aktivitas baik tetapi hasil belajarnya belum tuntas.

3. Strategi atau teknik pembelajaran kooperatif tipe jigsaw dapat membuat siswa lebih aktif dan tidak terlalu bergantung pada guru. Efekttif digunakan untuk membaca pemahaman.

\section{DAFTAR PUSAKA}

Alexander.1988. Teaching Reading. London : Scott Foresman.

Arends,I.Richard. 1988. Leaning to Teach.Boston Inc.McGraw-Hill Companies.

Direktorat Pendidikan Dasar Dan Menengah Depdiknas.2004. Materi Pelatihan Terintegrasi Bahasa Inggris. Jakarta.Depdiknas.

Djjiwandono, Istiarto 2002 Strategi Membaca Bahasa Inggris Jakarta, Gramedia Pustaka

Farida, Rahim, 2005 Pengajaran Membaca di SD Jakarta Bumi Aksara.

Guntur Tarigan, Henry . 1989. Pengajar Kompetensi Bahasa. Bandung, Angkasa

Kunandar. 2007 Guru Pofesional Implementasi Kurikulum Tingkat Satuan Pendidikan (KTSP) dan Sukses dalam Sertifikat Guru , Jakarta Raja Grafindo Persada 
2008 Langkahan Mudah Penelitian Tindakan Kelas sebagai Pengembangan, Jakarta, Raja Grafindo Persada

Lie, A, 2002. Cooperatif Learning (Memperaktekkan Cooperatif Learning di ruang-ruang kelas. Jakarta. Gramedia Widiasarana Indonesia
Lemlit Unimed 2008 Panduan Penyusunan Proposal Laporan Block Grand PTK

Untuk Guru. Medan Lem Lit

Sanjaya ，W.2008. Strategi Pembelajaran Berstandart Proses Pendidikan, Jakarta.

Tampubulon Dp 1987. Kemampuan Membaca Teknik Membaca Efektif dan Efisien. Bandung. Angkasa. 